\title{
Preliminary Assessment of Microplastic Pollution Index: A Case Study in Marmara Sea
}

\author{
Ibrahim $\operatorname{Tan}^{1, *}$ (1) \\ ${ }^{1}$ TUBITAK- Marmara Research Center, Environment and Cleaner Production Institute, 41470 Kocaeli, Türkiye.
}

\begin{abstract}
How to cite
Tan, I. (2022). Preliminary Assessment of Microplastic Pollution Index: A Case Study in Marmara Sea. Turkish Journal of Fisheries and Aquatic Sciences, 22(SI), TRJFAS20537. http://doi.org/10.4194/TRJFAS20537
\end{abstract}

\section{Article History}

Received 27 August 2021

Accepted 22 November 2021

First Online 23 November 2021

\section{Corresponding Author}

Tel.: +902626772953

E-mail: ibrahim.tan@tubitak.gov.tr

\section{Keywords}

Marmara Sea

Microplastic

Pollution

Coastal waters

MPI index

\begin{abstract}
Microplastics are global threat for marine environment, which originated from anthropogenic activities. Although human-induced effects on microplastics are well known, a holistic assessment has not been made. Here, we present the Microplastic Pollution Index (MPI); a fast, convenient, inexpensive and semi-quantitative tool for assessing land- and sea-based pressures on the sampling area. In this preliminary study, MPI were determined for eight different locations in Marmara Sea. According to the MPI results, The Marmara Sea is under the effect of several pressures such as urban and industrial wastewater, marine traffic, agricultural and residential activities on land. Furthermore, coastline morphology affects the retention time of water at the coastal zone. The highest MPI values were obtained from the Izmit and Bandırma Gulfs, whereas the lowest value was found at inflow of the Dardanelle Strait. MPI values and surface water abundance values for each station showed a linear relation $\left(R^{2}=0.60 ; F=7.619 ; D F=1, P<0.05\right)$. No correlation was found between MPI and microplastic abundance in water column and sediment. MPI is providing extensive information on microplastic pollution. The index can be useful to generate an effective monitoring strategy combating, restoring and protecting the coastal waters against the microplastic pollution.
\end{abstract}

\section{Introduction}

The marine and coastal environment are crucial to human life and is under the threat of plastic pollution (Derraik, 2002; Worm et al., 2006; Jang et al., 2014; Gall \& Thompson, 2015; Geyer et al., 2017; Karbalaei et al., 2018; Galgani et al., 2019; Ozturk \& Altinok, 2020). Plastic particles in the ecosystem (terrestrial and aquatic environment) that are consciously or unconsciously discharged by humans are being transported to the coastal and marine environments by sewerage, drainage systems, erosion, flooding, wind or rivers (Browne et al., 2015; Stanev \& Ricker, 2019; Turrell, 2019). Therefore, plastic litters are identified as a global problem by the EU and global initiatives, such as the United Nations Environment Programme (UNEP; see Sustainable Development Goal 14), as well as the G7 and G20. Furthermore, this global problem is being investigated by many researchers to quantify the amount of microplastics ( $<5 \mathrm{~mm}, \mathrm{MP}$ ) accumulated, to classify MPs and to determine microplastic accumulation hot spots. However, the link between the anthropogenic pressures 
and the MPs abundance needs to be investigated further.

Coastal areas shelter up to $45 \%$ of the entire human population (Flo et al., 2019). Human-induced pressures are concentrated in coastal areas such as ports, shipping activities, uncontrolled coastal landfills and dumping sites (Celik, 2002; Berkun et al., 2005; BSC, 2007). Lots of the studies in the field of plastic pollution were focused on land- based (e.g Topçu \& Öztürk, 2010; Topçu et al., 2013; Aytan et al., 2020) and sea based sources, (e.g. UNEP 2009; Aytan et al., 2020). However, their holistic assessment has not been made. Pollutant sources may vary according to the location. Either landbased activities or marine-based activities can be dominant, and sometimes both activities can coexist. To determine the methods of reducing marine litter, clarification of the pollutant sources should be a priority.

The risk assessment should be revealed using fast, convenient and inexpensive methods such as multimetric index methodologies. The steps of a multimetric index development have to include: (i) selection of candidate metrics; (ii) metric combination; (iii) index validation; (iv) index application to different human pressures; ( $v$ ) index interpretation; and (vi) index intercalibration (Borja \& Dauer, 2008; Borja et al., 2009, 2011).

Marmara Sea is an intercontinental and semienclosed small basin. It has a unique location between the Mediterranean and Black Sea, and connected to these seas via two straits, Çanakkale and İstanbul (Polat et al., 1997; Öztürk et al., 2000; Okus et al., 2008; Altıok et al., 2014; Aytan et al., 2021). Therefore, it is under the different land - sea based pressures such as urban and industrial (chemical, petrochemical, textile, tanning, metal extraction) wastewater, marine traffic, agricultural and residential activities on land (Tan et al., 2017, 2021). Most of the marine litter and microplastic studies in Turkey have been carried on the Mediterranean and Black Sea coasts (Aytan et al., 2016, 2020, 2021; Öztekin \& Bat, 2017; Öztekin et al., 2020; Güven et al., 2017). Only a limited number of study investigated the Marmara Sea coasts (Gürbüz, 2017; Tuncer et al., 2018; Çullu et al., 2021; Sari Erkan et al., 2021). The abundance of the particles showed variations for instance, Çullu et. al. 2021, found a mean abundance of 33 particles/L in Küçükçekmece Lagoon. Erkan et. al. 2021 found $276.1857 \pm 347.07,3497.02 \pm 7789.29$, $1487.52 \pm 2260.10,349.23 \pm 197.13$ and $813.75 \pm 561.77$ particle $/ \mathrm{km}^{2}$ in marine, pier, stream, deep sea discharge and sea discharge stations, respectively.

The aim of this study is to present simple, fast and convenient multimetric index, which is named Microplastic Pollution Index (MPI), to demonstration of the index's adequacy and to assess microplastic pressure on Marmara Sea coastal waters. The method will assess the pressure gradients on coastal waters and establish a pressure-impact relationship based on MPI and microplastic abundance in surface water, water column and sediment.

\section{Material and Methods}

\section{Study Area}

The Marmara Sea is a unique location and an inland sea. It connects the Black Sea to the Mediterranean Sea. The Marmara Sea is $70 \mathrm{~km}$ wide, $250 \mathrm{~km}$ long and has a surface area of $\sim 11,500 \mathrm{~km}^{2}$ (Tan et al., 2017). It has a wide continental shelf in the south and deep depressions in the north. The Marmara Sea has a twolayered hydrographic structure. Less saline ( 18 psu) Black Sea waters and very saline ( 38 psu) Mediterranean Sea waters are in the upper and lower layer, respectively (Ünlülata et al., 1990; Beşiktepe et al., 1994). The Marmara Sea is under the influence of many terrestrial and marine pressures due to the location and structure (Tan et al., 2017, 2021).

Istanbul, Kocaeli and Bursa provinces are in the Marmara Sea basin and constitute $25 \%$ of Turkey's population (TurkStat, 2021). These provinces have intense urban population, industrial and port activities. Also, as a result of its geostrategic location, the Sea of Marmara is subject to intense maritime transport activities. The northern shelf of the Sea of Marmara is under population and industrial activities pressures, whereas the diffuse source pressure effects the southern shelf (Figur 1).

Izmit (IZ30), Bandırma (BK1) and Gemlik (MD89A) bays are under high pressure of population, industry, port/marina, agricultural activities. Secondary or tertiary treatment has been located around in Izmit and Gemlik Gulf. However, the wastewater of the population located around Bandırma Bay discharges to the deep sea after physical treatment (Figure 1). In addition, the sampling stations that are located in gulfs are more effected by highway-emitted materials (Figure 1).

There are no aquaculture farms in the Marmara Sea. The Marmara Sea has intense marine traffic, as specially tanker traffic (Albayrak et. al., 2006). However, it has less tourism-based activities. Biga, Gonen and Susurluk rivers flow into the southern shelf of the Marmara Sea. In this study, Susurluk (SD1) and Gonen River (GD1) are the major rivers of the Marmara Sea are the primary diffuse pollutant sources of the southern shelf. Domestic wastewater, industrial (as specially, textile, plastic, rubber industry) wastewaters, and agricultural areas are the main pollution sources on these rivers (Figure 1). In addition, Susurluk River merges with Nilüfer Stream, where urban and industrial pressures are high (Küçükali, 2013).

\section{Microplastic Pollution Index}

The point and diffuse sources pollution is mainly the reason for the MPs pollution in the ecosystem (Horton et al. 2017; Su et al. 2020). Industrial products and sewage, Urban Wastewater Treatment (UWWT), tourism development, fishing plastic products, 
construction of farms and building, landfill and waste disposal, highways, aquaculture, marine traffic, port/marinas are the primary MPs pollution sources. In the current study, these mentioned activities were selected in Microplastic Pollution Index (MPI) methodology as an indicator of the MPs pollution. In addition, UWWT and population were assessed four classes in MPI due to the evaluation of MP discharges to water (Table 1).

In MPI methodology, industrial activities were evaluated with a four classes and textile, rubber and plastic industries were given the highest score due to the higher MP pollution contribution than the other sectors (UNEP, 2016; GESAMP, 2016). Agricultural activities such as tilling and crop rotation can facilitate MPs migration and fragmentation (Feng et al. 2020). Thus, the agricultural pollution was assessed in the MPI index in four classes.

Recent studies have shown that large amounts of MPs are emitted from highway or high-density traffic areas (Knight et al., 2020; Järlskog et al. 2021). Thus, the distance of the road from the sampling station was

Table 1. Pressure activities and their definitions.

\begin{tabular}{|c|c|c|}
\hline Pressure Activities & Score & Definition \\
\hline \multirow[t]{4}{*}{ Urban Wastewater Treatment Planet (UWWT) } & 3 & None \\
\hline & 2 & Pretreatment \\
\hline & 1 & Second Treatment \\
\hline & 0 & Advanced Treatment \\
\hline \multirow[t]{4}{*}{ Population (people) } & 3 & $>500.000$ \\
\hline & 2 & $100.000-500.000$ \\
\hline & 1 & $100.000-10.000$ \\
\hline & 0 & $<10.000$ \\
\hline \multirow[t]{4}{*}{ Distance from Highway (km) } & 3 & $<1$ \\
\hline & 2 & $1-2$ \\
\hline & 1 & $2-3$ \\
\hline & 0 & $>3$ \\
\hline \multirow[t]{4}{*}{ Sampling Date Weather } & 3 & The weather was windy and rainy on the sampling date \\
\hline & 2 & $\begin{array}{c}\text { The weather was windy and rainy two days ago sampling } \\
\text { The weather was windy and rainy one week ago }\end{array}$ \\
\hline & 1 & sampling \\
\hline & 0 & Calm weather \\
\hline \multirow[t]{3}{*}{ Port / Marina } & 2 & High \\
\hline & 1 & Medium \\
\hline & 0 & None \\
\hline \multirow[t]{4}{*}{ Aquaculture } & 3 & High \\
\hline & 2 & Medium \\
\hline & 1 & Low \\
\hline & 0 & None \\
\hline \multirow[t]{4}{*}{ Industry } & 3 & Textile, Plastic, Rubber Industry \\
\hline & 2 & High \\
\hline & 1 & Medium \\
\hline & 0 & None \\
\hline \multirow[t]{4}{*}{ Agriculture } & 3 & High \\
\hline & 2 & Medium \\
\hline & 1 & Low \\
\hline & 0 & None \\
\hline \multirow{4}{*}{ Tourism } & 3 & High \\
\hline & 2 & Medium \\
\hline & 1 & Low \\
\hline & 0 & None \\
\hline \multirow[t]{2}{*}{ Solid Waste } & 1 & Wild Storage \\
\hline & 0 & Landfill \\
\hline \multirow[t]{4}{*}{ Marine Traffic } & 3 & High \\
\hline & 2 & Medium \\
\hline & 1 & Low \\
\hline & 0 & None \\
\hline \multirow[t]{4}{*}{ Strahler Scale } & 3 & $>5$ \\
\hline & 2 & $4-5$ \\
\hline & 1 & $3-4$ \\
\hline & 0 & $<3$ \\
\hline \multirow[t]{3}{*}{ Coastal Morphology } & 0 & 1 \\
\hline & 1 & 0.75 \\
\hline & 2 & 1.25 \\
\hline
\end{tabular}


evaluated in the current study. The variable based on the proximity of sampling stations to the road thus, the value classified as a high risk below $1 \mathrm{~km}$ and slightly risk over $3 \mathrm{~km}$.

Since rivers play an important role in transporting MPs, Strahler scale was considered in determining the size of the stream in evaluating the MP pollution. The scale ranges from 0 to 7 . The number gets larger, that shows more sub-branches are being connected to the river (Table 1 ).

In the classification of aquaculture activities in the MPI, UNEP and GESAMP guidelines were used. Due to limited data about the MP pollution at port and marinas (Chen \& Liu, 2013; Masiá et. Al., 2021), marine traffic was evaluated with three classes.

In order to evaluate the touristic activities such as water sports, scuba diving, snorkelling, kayaking and motor gliders etc. on the contribution of MP pollution, the pressure activity has been divided into 4 classes depending on the tourism intensity.

Although airborne microplastic particles (AMP) from terrestrial origins were found in coastal regions and these can travel tens of kilometres (Trainic et. al 2020), AMP was not assessed in this study.

Microplastic Pollution Index is a specific combination and estimation of coastal pressures related to MPs. The calculation of the MPI of a station requires the quantified pressures and the partial pressures to be summed, and then to be multiplied by a correction factor related to coastline morphology (Table 1). The correction factor used by Flo et. al. 2011 is determined by the shape of the shore and plays a role in reducing or increasing the effect of the pressure according to the water residence time (Flo et. al., 2011). The correction factor or coastal morphology takes the values $1.25,1$ and 0.75 according to the coastline is concave, straight and convex, respectively (Table 1 ). Concave coastline has low water current and high water residence time; also, this enhances the influences of the anthropogenic pressures (Flo et al., 2019). In contrast, the convex coastline has high water currents and low water residence time; these factors dilute the anthropogenic pressures. Mostly, land-based sources determine the impact of pressures on the straight coastline.

In MPI methodology, some of the pressure indicators were measurable variables such as urban wastewater treatment, human population, distance from highway, and sampling date weather; and the other variables were estimated using expert judgement based on the knowledge of the study areas. For each station, pressure gradients were assessed within $3000 \mathrm{~m}$ surrounding the station using satellite image (Figure 1).

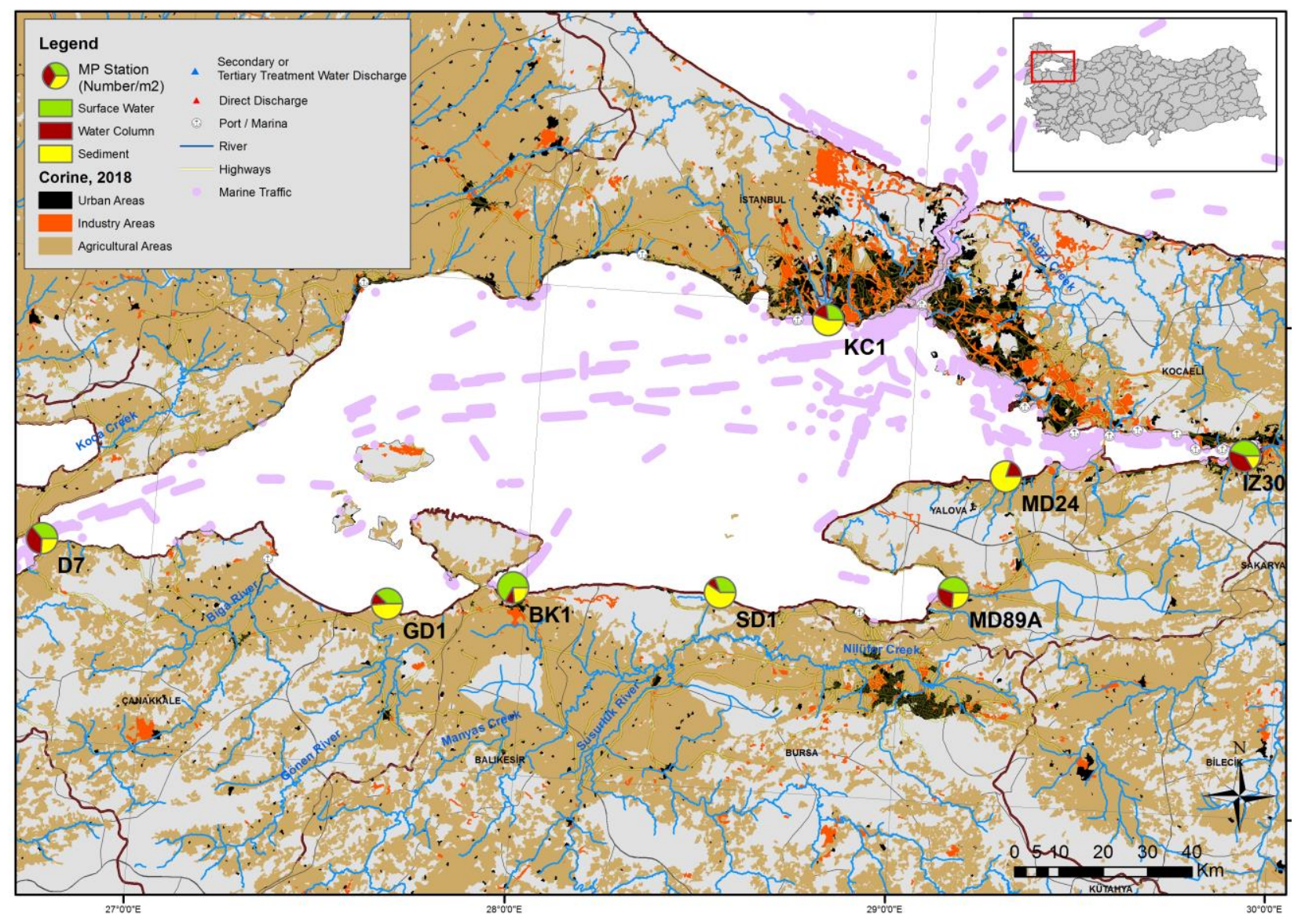

Figure 1. MP station, abundance, pressure activities and land use of Marmara Sea (IZ30: Izmit, MD24: Yalova, MD89A: Gemlik, SD1:Susurluk River, BK1: Bandırma, GD1: Gönen River, D7: Dardanelles Strait, KC1: Küçükçekmece) 
Using geographical information system (GIS) tools, such as google earth and ArcGIS, are crucial for evaluating the index indicators. Microplastic Pollution Index were calculated using the following Equation (1):

MPI = (UWWT + Agriculture + Industry + Distance from Highway + Landfill + Tourism + Aquaculture + Marine Traffic + Port + Sampling Date Weather+ Strahler Score) *Coastal Morphology (1)

The pressure intensity scale has been classified as five levels of evaluation and assigning scores range from 0 to 3 for each pressure type within the stations. The classification was proposed as (i) no pressure (0 to 4); (ii) low pressure (4 to 15); (iii) moderate pressure (15 - 20); (iv) high pressure (20 - 25); (v) very high pressure (2541).

In this study, previously reported MP data from surface waters, water column and sediment at 8 stations (Figure 1) in the Marmara Sea (Gürbüz, 2017) were compared with the values of MPI.

\section{Results and Discussion}

Microplastic pollution is mostly a result of the human-induced pressures such as UWWT and industrial discharges, tourism, agriculture, surface runoff, aquaculture, marine traffic, ports, shipping, and uncontrolled coastal landfills (e.g. Topçu \& Öztürk, 2010; Topçu et al., 2013; Aytan et al., 2020). Amount of the human-induced pressures is crucial to determine for establishing prevention programs of MP. In a recent study, MP pollution was investigated in Yangtze River and results showed that considerable amount of MPs generated in large river catchments are not transported to the sea (Xiong et al., 2019). In addition, Zhao et al. (2019) assessed MP transportation by rivers to the sea and its seasonal effect. The study found that over 16-20 trillion particles entered the sea from the surface water layer of the Changjiang River in 2017. Feng et. al. (2020) investigated the effect of the population density, night light index, area of facility agriculture, and output value of industries indicators on the MP spatial distribution and pollution. They found night light index correlated better with the population. Also, tourism-based activities were the main pressure in water bodies. Both studies were focused single indicator for MP pollution. However, cumulative pressure assessments could be a better method to clarify the MP pollution

Microplastic Pollution Index is a fast, convenient, inexpensive and semi-quantitative assessment methodology. It evaluates land- and sea-based pressures of the studied area. It ranges from 0 to 41 and evaluates in 5 classes. A low MPI value shows no or slight land-based and sea-based pressures, whereas a high value represents a high impact.

The Marmara Sea is under the effects of several pressures, which can also be seen from the MPI results. Furthermore, currents and coastline morphology effect the retention time of water at the coastal zone. IZ30 and BK1 stations are located in the Izmit and Bandırma Gulfs.
These Gulfs are located in the south of the Marmara Sea, respectively. They have intense industrial, port and transportation activities (Figure 1). They are both also characterized with river inputs, animal husbandry, and agricultural activities. The Izmit and Bandırma Gulfs are classified as under very high pressure of MP pollution and their MPI values were calculated as 25 and 27,5, respectively. Gemlik Gulf has very similar activities to the Izmit and Bandırma Gulfs, except that it has less marine traffic (Figure 1). Therefore, MD89A station in the Gemlik Gulf showed a MPI value of 18,75 and classified as under high risk (Table 2). Gulf ecosystems are under the influence of point/diffuse sources and other pressures. Due to the low water exchange capacity of these ecosystems, they are suitable for the accumulation of pollutants (Shahidul Islam \& Tanaka, 2004).

SD1 station is at the mouth of the Susurluk River. Susurluk River merges with Nilüfer Stream, where urban and industrial pressures are high (Küçükali, 2013). Therefore, Susurluk River is under the influence of heavily polluted waters of Nilüfer Stream (Figure 1). The MPI value of SD1 station showed that it was at the moderate risk. MD24 station is located in the outer boundary of the Izmit Bay, which is close to Yalova Province and has fewer pressure activities (Table 1). At the entrance of the Dardanelles Strait, D7 station has the lowest MPI due to the high current speed. These results on microplastic abundance are from limited sampling; thus long term monitoring will help for better understanding the sources of MPs in the region.

The pressure index MPI calculated for eight stations (Table 1) showed that maximal values, corresponding to high human impacts, and the lowest, corresponding to low human pressure. MPI values and surface water abundance values for each station showed a good linear relation $\left(R^{2}=0.60 ; F=7.619 ; D F=1\right.$, $\mathrm{P}<0.05)$ (Figure 2). No correlation was found between $\mathrm{MPI}$ and the MP abundance in water column and sediment (Figure. 2). Therefore, this index was tested with the limited data. The reason it did not correlate with sediment and water column MP concentration might be densities of polymer is not considered in this study. More and detailed data is need to be used to test to applicability of MPI for the water column and sediment.

MPs can barely be seen with naked eye, it is a hard task to weight and count microplastics. In addition, physical conditions are affecting the sampling and abundance values of MP such as weather conditions (winds and rains), waves, and currents. Therefore, this study needs to be repeated with more station data, especially from water column and sediment.

The origin and pathways of MP is crucial to identify in the marine environment. Furthermore, the land- and sea-based pressure activities should be taking into consideration for define sources of the MP. This problem should be determined by applying different scientific approaches (Mira Veiga et al., 2016; Moora \& 


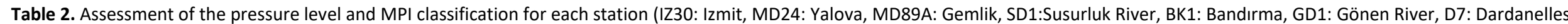
Strait, KC1: Küçükçekmece)

\begin{tabular}{|c|c|c|c|c|c|c|c|c|c|c|c|c|c|c|c|}
\hline Station & UWWT & Population & $\begin{array}{c}\text { Distance from } \\
\text { Highway }\end{array}$ & $\begin{array}{c}\text { Samplig } \\
\text { Date } \\
\text { Weather }\end{array}$ & Port/Marina & Agriculture & Industry & Aquaculture & Tourism & Solid Waste & Marine Traffic & Strahler Score & $\begin{array}{c}\text { Coastal } \\
\text { Morphology }\end{array}$ & MPI Score & MPI Class. \\
\hline IZ30 & 2 & 3 & 2 & 0 & 2 & 2 & 3 & 0 & 1 & 0 & 3 & 2 & 2 & 25 & 5 \\
\hline MD24 & 1 & 2 & 0 & 0 & 1 & 1 & 2 & 0 & 1 & 0 & 2 & 0 & 0 & 12,5 & 2 \\
\hline MD89A & 2 & 3 & 2 & 0 & 1 & 2 & 2 & 0 & 1 & 0 & 2 & 0 & 2 & 18,75 & 4 \\
\hline SD1 & 3 & 1 & 0 & 0 & 0 & 3 & 3 & 0 & 0 & 1 & 3 & 3 & 0 & 17 & 3 \\
\hline BK1 & 3 & 3 & 2 & 0 & 3 & 2 & 3 & 0 & 1 & 2 & 3 & 0 & 2 & 27,5 & 5 \\
\hline GD1 & 1 & 1 & 0 & 0 & 0 & 2 & 1 & 0 & 1 & 1 & 1 & 3 & 0 & 11 & 2 \\
\hline D7 & 0 & 1 & 0 & 0 & 0 & 1 & 2 & 0 & 0 & 0 & 3 & 0 & 1 & 5,25 & 2 \\
\hline KC1 & 1 & 1 & 0 & 0 & 0 & 0 & 1 & 0 & 0 & 0 & 2 & 0 & 0 & 5 & 2 \\
\hline
\end{tabular}

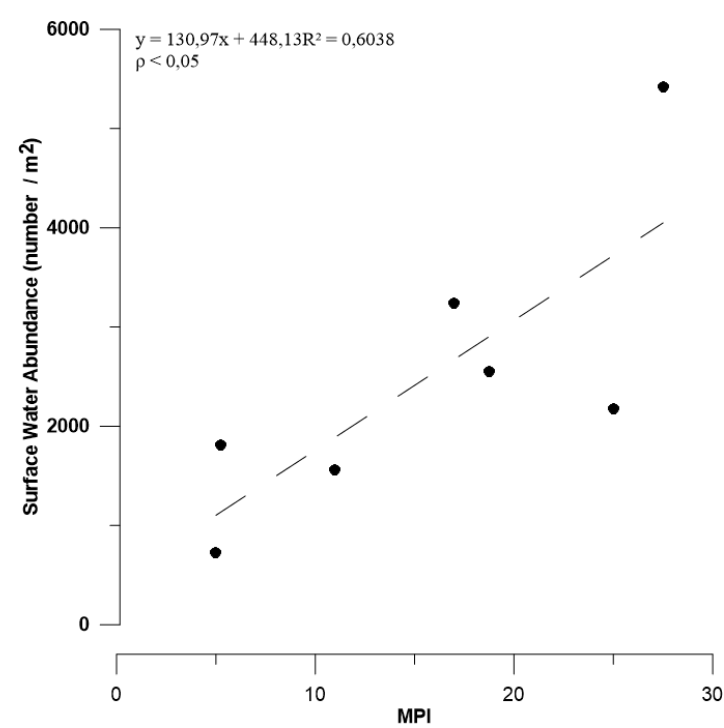

(a)

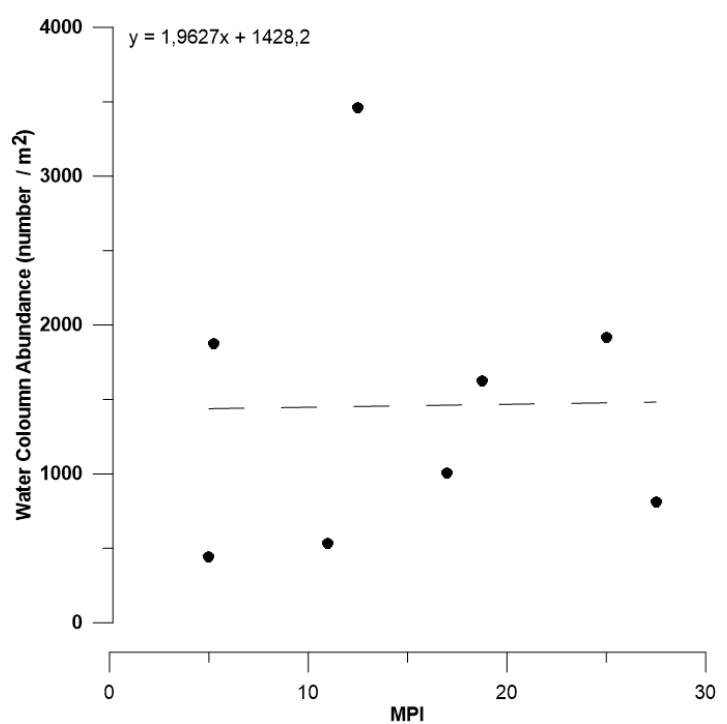

(b)

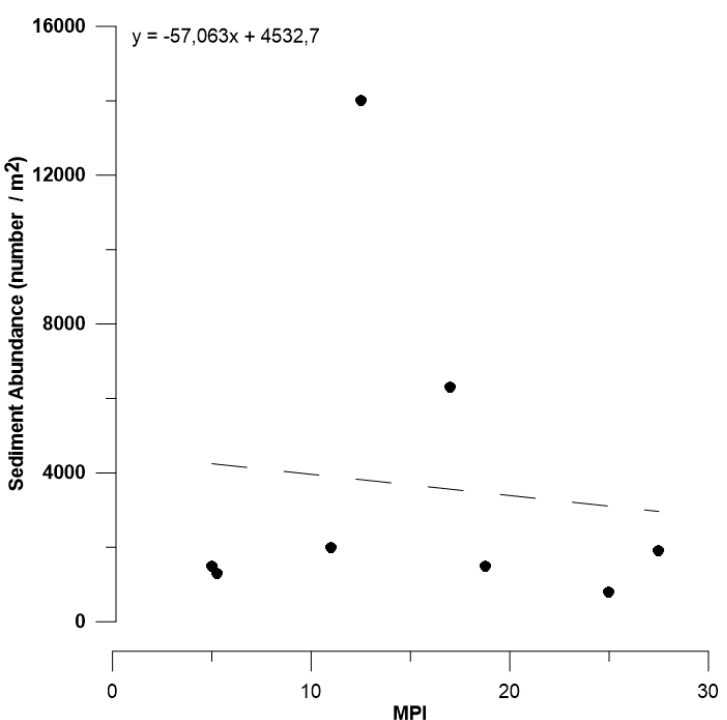

(c)

Figure 2. Surface water (a), water column (b), and sediment (c) abundance values correlation with MPI for each station in the Marmara Sea 
Piirsalu, 2016). In addition, to identify MP abundance and risk management need an effective monitoring strategy. Thus, multimetric index methodologies such as MPI play crucial role to create monitoring strategies.

Several directives, guidelines and mobile applications exist, associated with the quantification, control and management of microplastics such as The Marine Strategy Framework Directive (MSFD 2008/56/EC; EC 2008), The Single-Use Plastics Directive (SUPD 2019/904/EC; EC 2019), UNEP - Marine Plastic Debris and Microplastics- Global Lessons and Research to Inspire Action and Guide Policy Change, and Marine Litter Watch. However, the MP hot spot areas have not yet been adequately determined. MP pollution has a transboundary/supranational origin. Therefore, tracing MPs from their source is a major challenge in assessing $\mathrm{MP}$ abundance and risk management (Rivers et al., 2019).

\section{Conclusion}

In this study, a fast, convenient, inexpensive and semi-quantitative assessment methodology to evaluates land and sea-based pressures for the MP pollution were developed. Microplastic Pollution Index is a mutlimetric index and a scientific approach that can assess MP pollution risk for each station or sampling area.

Present study shows that MPI index is good fit to the surface water MPs results, but it needs to be studied and validated with more data. However, MPI results showed that the index is able to distinguish between land- and sea-based sources in the sampling area. On the other hand, MPI provides information on MP pollution, which is useful to create effective monitoring strategy. Furthermore, environmental managers can use this information to combat, restore and protect coastal waters against the MP pollution.

Microplastic Pollution Index is still under development. Future studies may focus on assessing index with more detailed data (surface, water column and sediment) to make a robust tool. In addition, MPI may test with different types of MPs to estimate the primary and secondary sources of the pressure activity.

\section{Ethical Statement}

The author declares no ethical statement.

\section{Funding Information}

The author declares no Funding Information.

\section{Conflict of Interest}

The author(s) declare that they have no known competing financial or non-financial, professional, or personal conflicts that could have appeared to influence the work reported in this paper.

\section{Acknowledgements}

We wish to sincerely thank to Özlem Gürbüz, MSc. and her advisor Assoc. Prof. Ahsen Yüksek (Institute of Marine Sciences and Management of Istanbul University, Turkey) for allowing me to use the data of the Sea of Marmara Microplastic Characterization and Distribution master thesis. We also thank to Gülsima Dilek Usluer, PhD for contribution and proof-reading the manuscript.

\section{References}

Albayrak, S., Balkis, H., Zenetos, A., Kurun, A., Kubanç, C. (2006). Ecological quality status of coastal benthic ecosystems in the Sea of Marmara. Marine Pollution Bulletin, 52(7), 790-799. https://doi.org/10.1016/j.marpolbul.2005.11.022

Altıok, H., Aslan, A., Övez, S., Demirel, N., Yüksek, A., Kıratlı, N., Okuş, E. (2014). Influence of the extreme conditions on the water quality and material exchange flux in the Strait of Istanbul. Journal of Marine Systems, 139, 204-216. https://doi.org/10.1016/j.jmarsys.2014.06.005

Aytan, U., Valente, A., Senturk, Y., Usta, R., Esensoy Sahin, F. B., Mazlum, R. E., Agirbas, E. (2016). First evaluation of neustonic microplastics in Black Sea waters. Marine Environmental Research, 119, 22-30.

https://doi.org/10.1016/j.marenvres.2016.05.009

Aytan, U., Esensoy, F. B., Karacan, F., (2020). Beach Litter on Sarayköy Beach (SE Black Sea): Density, Composition, Possible Sources and Associated Organisms. Turk. J. Fish.Aquat. Sci. 20(2), 137-145. http://doi.org/10.4194/1303-2712-v20_2_06

Aytan, U., Esensoy, F. B., Senturk, Y. (2021). Microplastic ingestion and egestion by copepods in the Black Sea. Science of The Total Environment, 150921.

Berkun, M., Aras, E., Nemlioglu, S. (2005). Disposal of solid waste in Istanbul and along the Black Sea coast of Turkey. Waste Management, 25(8), 847-855. https://doi.org/10.1016/j.wasman.2005.04.004

Beşiktepe, Ş. T., Sur, H. I.., Özsoy, E., Latif, M. A., Oǧuz, T., Ünlüata, Ü. (1994). The circulation and hydrography of the Marmara Sea. Progress in Oceanography, 34(4), 285334. https://doi.org/10.1016/0079-6611(94)90018-3

Borja, A., Barbone, E., Basset, A., Borgersen, G., Brkljacic, M., Elliott, M., Trayanova, A. (2011). Response of single benthic metrics and multi-metric methods to anthropogenic pressure gradients, in five distinct European coastal and transitional ecosystems. Marine Pollution Bulletin, 62(3), 499-513. https://doi.org/10.1016/j.marpolbul.2010.12.009

Borja, A., Dauer, D. M. (2008). Assessing the environmental quality status in estuarine and coastal systems: Comparing methodologies and indices. Ecological Indicators, 8(4), 331-337. https://doi.org/10.1016/j.ecolind.2007.05.004

Borja, A., Ranasinghe, A., Weisberg, S. B. (2009). Assessing ecological integrity in marine waters, using multiple indices and ecosystem components: Challenges for the future. Marine Pollution Bulletin, 59(1), 1-4. https://doi.org/10.1016/j.marpolbul.2008.11.006

Browne, M. A., Chapman, M. G., Thompson, R. C., Amaral Zettler, L. A., Jambeck, J., Mallos, N. J. (2015). Spatial and Temporal Patterns of Stranded Intertidal Marine Debris: 
Is There a Picture of Global Change? Environmental Science \& Technology, 49(12), 7082-7094. https://doi.org/10.1021/es5060572

BSC. (2007). Marine Litter in the Black Sea Region: a Review of the Problem (Black Sea Commission Publications 2007-1, Issue.

Celik, F. (2002, 5-8 November 2002). A Case Study: Interstate Highway in the Black Sea Coast Proc. 4th Conf. on Turkish Coast and Coastal Areas, Izmir, Turkey.

Chen, C. L., Liu, T. K. (2013). Fill the gap: Developing management strategies to control garbage pollution from fishing vessels. Marine Policy, 40, 34-40. https://doi.org/10.1016/j.marpol.2013.01.002

Cole, M., Lindeque, P., Halsband, C., Galloway, T. S. (2011). Microplastics as contaminants in the marine environment: A review. Marine Pollution Bulletin, 62(12), 2588-2597.

https://doi.org/10.1016/j.marpolbul.2011.09.025

Çullu, F. A., Sönmez, V. Z., Sivri, N. (2021). Microplastic contamination in surface waters of the Küçükçekmece Lagoon, Marmara Sea (Turkey): Sources and areal distribution. Environmental Pollution, 268, 115801. https://doi.org/10.1016/j.envpol.2020.115801

Derraik, J. G. B. (2002). The pollution of the marine environment by plastic debris: a review. Marine Pollution Bulletin, 44(9), 842-852.

https://doi.org/10.1016/S0025-326X(02)00220-5

Feng, S., Lu, H., Tian, P., Xue, Y., Lu, J., Tang, M., Feng, W. (2020). Analysis of microplastics in a remote region of the Tibetan Plateau: Implications for natural environmental response to human activities. Science of The Total Environment, 739, 140087. https://doi.org/10.1016/j.scitotenv.2020.140087

Flo, E., Camp, J., Garcés, E. (2011). Assessment Pressure methodology, Land Uses Simplified Index (LUSI), BQE Phytoplankton; Spain- Catalonia.

Flo, E., Garcés, E., Camp, J. (2019). Land Uses Simplified Index (LUSI): Determining Land Pressures and Their Link with Coastal Eutrophication [Original Research]. 6(18). https://doi.org/10.3389/fmars.2019.00018

Galgani, L., Beiras, R., Galgani, F., Panti, C., Borja, A. (2019). Editorial: Impacts of Marine Litter [Editorial]. 6(208). https://doi.org/10.3389/fmars.2019.00208

Gall, S. C., Thompson, R. C. (2015). The impact of debris on marine life. Marine Pollution Bulletin, 92(1), 170-179. https://doi.org/10.1016/j.marpolbul.2014.12.041

GESAMP. (2016). Sources, fate and effects of microplastics in the marine environment: second phase assessment part two. Rep.Stud. GESAMP.

Geyer, R., Jambeck, J. R., Law, K. L. (2017). Production, use, and fate of all plastics ever made. Science Advances, 3(7), e1700782. https://doi.org/10.1126/sciadv.1700782

Guneroglu, A. (2010). Marine litter transportation and composition in the Coastal Southern Black Sea Region. Sci. Res. Essays, 5 (3), 296-303.

Gürbüz, Ö. (2017). Marmara denizi mikroplastik karakterizasyonu ve dağılımı (Master thesis, Deniz Bilimleri ve İşletmeciliği Enstitüsü).

Güven, O., Gökdağ, K., Jovanović, B., \& Kıdeyş, A.E. (2017). Microplastic litter composition of the Turkish territorial waters of the Mediterranean Sea, and its occurrence in the gastrointestinal tract of fish. Environmental pollution, 223, 286-294.

Horton, A. A., Walton, A., Spurgeon, D. J., Lahive, E., Svendsen, C. (2017). Microplastics in freshwater and terrestrial environments: evaluating the current understanding to identify the knowledge gaps and future research priorities. Science of the total environment, 586, 127141. https://doi.org/10.1016/j.scitotenv.2017.01.190

Jang, Y. C., Hong, S., Lee, J., Lee, M. J., Shim, W. J. (2014). Estimation of lost tourism revenue in Geoje Island from the 2011 marine debris pollution event in South Korea. Marine Pollution Bulletin, 81(1), 49-54. https://doi.org/10.1016/j.marpolbul.2014.02.021

Järlskog, I., Strömvall, A. M., Magnusson, K., Galfi, H., Björklund, K., Polukarova, M., Andersson-Sköld, Y. (2021). Traffic-related microplastic particles, metals, and organic pollutants in an urban area under reconstruction. Science of the Total Environment, 774, 145503.https://doi.org/10.1016/j.scitotenv.2021.145503

Karbalaei, S., Hanachi, P., Walker, T. R., Cole, M. (2018). Occurrence, sources, human health impacts and mitigation of microplastic pollution. Environmental Science and Pollution Research, 25(36), 36046-36063. https://doi.org/10.1007/s11356-018-3508-7

Küçükali, U. (2013). Basin-scale ecological isk assessment methodology, example of Nilufer Creek and its subbasins. Journal of International Scientific Publications, 7.

Knight, L. J., Parker-Jurd, F. N., Al-Sid-Cheikh, M., Thompson, R. C. (2020). Tyre wear particles: an abundant yet widely unreported microplastic? Environmental Science \& Pollution Research, 27(15). https://doi.org/10.1007/s11356-020-08187-4

Masiá, P., Ardura, A., Gaitán, M., Gerber, S., Rayon-Viña, F., Garcia-Vazquez, E. (2021). Maritime ports and beach management as sources of coastal macro-, meso-, and microplastic pollution. Environmental Science and Pollution Research, 1-10. https://doi.org/10.1007/s11356-021-12821-0

Mira Veiga, J., Fleet, D., Kinsey, S., Nilsson, P., Vlachogianni, T., Werner, S., Cronin, R. (2016). Identifying Sources of Marine Litter - TGML Report. https://doi.org/10.2788/018068

Moora, H., Piirsalu, E. (2016). Sources and pathways of marine litter, Background report. (Project BLASTIC, plastic waste pathways into the Baltic Sea, Issue.

Okus, E., Ozturk, I., Sur, H. I., Yuksek, A., Tas, S., Aslan-Yilmaz, A., Aydin, A. F. (2008). Critical evaluation of wastewater treatment and disposal strategies for Istanbul with regards to water quality monitoring study results. Desalination, 226(1), 231-248. https://doi.org/10.1016/j.desal.2007.02.109

Oztekin, A., \& Bat., L. (2017). Microlitter pollution in sea water: a preliminary study from Sinop Sarikum coast of the southern Black Sea. Turkish Journal of Fisheries and Aquatic Sciences, 17, 1431-1440. http://doi.org/10.4194/1303-2712-v17_6_37

Ozturk, R.C., \& Altinok, I. (2020). Interaction of plastics with marine species. Turkish Journal of Fisheries and Aquatic Sciences, 20(8), 647-658. http://doi.org/10.4194/13032712-v20_8_07

Ozturk, A., Bat, L., \& Baki, O.G. (2020). Beach litter pollution in Sinop Sarikum Lagoon Coast of the Southern Black Sea. Turkish Journal of Fisheries and Aquatic Sciences, 20(3), 197-205. http://doi.org/10.4194/1303-2712-v20_3_04

Öztürk, B., Kadıoğlu, M., Öztürk, H. (2000). Sources, fate and effects of microplastics in the marine environment: second phase assessment part two (TÜDAV Yayın no. 5, Issue. 
Polat, S. C., Tuğrul, S., Çoban, Y., Basturk, O., Salihoglu, I. (1997). Elemental composition of seston and nutrient dynamics in the Sea of Marmara. Hydrobiologia, 363(1), 157-167. https://doi.org/10.1023/A:1003117504005

Rivers, M., Gwinnett, C., Woodall, L. (2019). Quantification is more than counting: Actions required to accurately quantify and report isolated marine microplastics. Marine Pollution Bulletin, 139, 100-104. https://doi.org/10.1016/j.marpolbul.2018.12.024

Sari Erkan, H., Bakaraki Turan, N., Albay, M., Onkal Engin, G. (2021). A preliminary study on the distribution and morphology of microplastics in the coastal areas of Istanbul, the metropolitan city of Turkey: The effect of location differences. Journal of Cleaner Production, 307, 127320. https://doi.org/10.1016/j.jclepro.2021.127320

Shahidul Islam, M., Tanaka, M. (2004). Impacts of pollution on coastal and marine ecosystems including coastal and marine fisheries and approach for management: a review and synthesis. Marine Pollution Bulletin, 48(7), 624-649.

https://doi.org/10.1016/j.marpolbul.2003.12.004

Stanev, E. V., Ricker, M. (2019). The Fate of Marine Litter in Semi-Enclosed Seas: A Case Study of the Black Sea [Original Research]. 6(660). https://doi.org/10.3389/fmars.2019.00660

Su, L., Nan, B., Craig, N. J., Pettigrove, V. (2020). Temporal and spatial variations of microplastics in roadside dust from rural and urban Victoria, Australia: Implications for diffuse pollution. Chemosphere, 252, 126567. https://doi.org/10.1016/j.chemosphere.2020.126567

Tan, İ., Beken, Ç., Oncel, S. (2017). Pressure-Impact analysis of the coastal waters of Marmara Sea Fresenius Environmental Bulletin, 26.

Tan, i. (2021). Marmara denizi körfezlerinin baskı-etki durumu ve ötrofikasyon açısından değerlendirilmesi (Evaluation of Marmara Sea bays in terms of pressure-impact status and eutrophication). https://doi.org/10.3153/AR21014

Topçu, E. N., Öztürk, B. (2010). Abundance and composition of solid waste materials on the western part of the Turkish
Black Sea seabed. Aquatic Ecosystem Health \& Management, 13(3), 301-306. https://doi.org/10.1080/14634988.2010.503684

Topçu, E. N., Tonay, A. M., Dede, A., Öztürk, A. A., Öztürk, B. (2013). Origin and abundance of marine litter along sandy beaches of the Turkish Western Black Sea Coast. Marine Environmental Research, 85, 21-28. https://doi.org/10.1016/j.marenvres.2012.12.006

Trainic, M., Flores, J. M., Pinkas, I., Pedrotti, M. L., Lombard, F., Bourdin, G., Koren, I. (2020). Airborne microplastic particles detected in the remote marine atmosphere. Communications Earth \& Environment, 1 (1 ), 1-9. https://doi.org/10.1038/s43247-020-00061

TurkStat (Turkish Statistical Institute). (2021). Address-Based Population Registration System Data, WWW Page. (accessed: 14.07.2021)

Turrell, W. R. (2019). Spatial distribution of foreshore litter on the northwest European continental shelf. Marine Pollution Bulletin, 142, 583-594. https://doi.org/10.1016/j.marpolbul.2019.04.009

UNEP (2009). Marine Litter: A Global Challenge. United Nations Environment Programme, Issue.

UNEP. (2016). Marine Plastic Debris and Microplastics-Global Lessons and Research to Inspire Action and Guide Policy Change United Nations Environment Programme, Issue.

Ünlülata, Ü., Oğuz, T., Latif, M. A., Özsoy, E. (1990). On the Physical Oceanography of the Turkish Straits. In L. J. Pratt (Ed.), The Physical Oceanography of Sea Straits (pp. 2560). Springer Netherlands. https://doi.org/10.1007/97894-009-0677-8_2

Worm, B., Barbier, E. B., Beaumont, N., Duffy, J. E., Folke, C., Halpern, B. S., Watson, R. (2006). Impacts of Biodiversity Loss on Ocean Ecosystem Services. 314(5800), 787-790. https://doi.org/10.1126/science.1132294 \%J Science

Xia, W., Rao, Q., Deng, X., Chen, J., Xie, P. (2020). Rainfall is a significant environmental factor of microplastic pollution in inland waters. Science of the Total Environment, 732, 139065.

https://doi.org/10.1016/j.scitotenv.2020.139065 